\title{
Least limiting water range in Oxisols under different levels of machine traffic
}

\author{
Karina de Vares Rossetti*, José Frederico Centurion'
}

'Paulista State University, Jaboticabal, SP, Brazil

*Corresponding author, e-mail: krossetti@bol.com.br

\begin{abstract}
This work aimed, to evaluate the structural behavior of Oxisols based on the least limiting water range (LLWR) and establish relations with corn crop. The experiment was carried out in a randomized block design with five treatments and four replications. Soil samples collected at the layer of 0-0.20 m depth in a Haplustox (LVd) and an Eutrustox (LVef) were used. The compaction treatments consisted of $\mathrm{TO}=$ no additional compaction; $\mathrm{Tl}$ and $\mathrm{T} 2=$ two and four passes with a $4 \mathrm{t}$ tractor, respectively; $\mathrm{T} 3$ and $\mathrm{T} 4=$ two and four passes with a $10 t$ tractor, respectively. The range of LLWR variation in the LVd was the lowest one and varied from 0.01 to $0.04 \mathrm{~m}^{3} \mathrm{~m}^{-3}$, whereas in the LVef varied from 0.03 to $0.13 \mathrm{~m}^{3} \mathrm{~m}^{-3}$ for the critical soil penetration resistance (PRC) of 2 $\mathrm{MPa}$. It was observed that critical bulk density $(B D C)$ values were 1.76 and $1.40 \mathrm{Mg} \mathrm{m}^{-3}$ in the $\mathrm{LVd}$ and the LVef, respectively. The highest frequency of bulk density (BC $\geq B D C$ ) occurred from the $\mathrm{T} 1$ to T4 (LVd) and from the T2 to T4, however, a reduction in corn yield was not observed. The determination of the LLWR was efficient and complementary for identifying more favorable or more impeditive conditions to compaction in the LVef for the corn crop development in relation to the LVd.
\end{abstract}

Keywords: Soil compaction, tractor traffic, soil structure

\section{Introduction}

As natural ecosystems are being replaced by intense and continuous agricultural activities, the soil physical properties may undergo temporary or permanent changes and consequently may lead to unfavorable conditions for the plant development. Therefore, the soil physical degradation is established and generally related to the losses of organic matter and structural integrity of the soils (Guimarães et al., 2013).

The soil bulk density, porous system, soil penetration resistance, soil aggregation, S-index, soil water retention, the degree of compaction, water infiltration, least limiting water range (LLWR)

etc., are the most commonly attributes to evaluate soil degradation. Therefore, laboratory analyses are still performed, although they are expensive and time-consuming, mainly, when there is a high number of samples and attributes evaluated. This is because, the visual quantification of the soil structural behavior in a given agricultural management is a hard task (Omuto, 2008).

The LLWR is a soil quality index that integrates into a single variable (soil bulk density) the factors that directly affect the plant growth. The decreasing of LLWR reduces the range in which soil moisture can vary without restricting plant growth, related to water availability, aeration, and soil penetration resistance. 
Therefore, it can be considered a well-established index to evaluate the quality of cultivated soils (Cavalieri et al., 2011). However, for Gubiani et al. (2013) the use of LLWR is imprecise to estimate the risk of losses in grain production related to soil compaction.

Another way to evaluate the use of LLWR is through of the critical soil bulk density (BDC), which occurs when the LLWR is zero, that is, the one in which the lower limit crosses the upper limit of the interval. From this condition, severe restrictions to planting growth occur. In a medium-textured red Oxisol, Freddi et al. (2009) found that the BDc was $1.46 \mathrm{~kg} \mathrm{dm}^{-3}$ at the layer of 0-0.30 m depth in different compaction levels induced by tractors. At the same soil class after the third growth cycle of sugarcane, Cavalieri et al. (2011) found that the BDc values were 1.76 and $1.77 \mathrm{Mg} \mathrm{m}^{-3}$, at the layers of $0-0.20\left(292 \mathrm{~g} \mathrm{~kg}^{-1}\right.$ clay) and $0.20-0.40 \mathrm{~m}$ (365 $\mathrm{g} \mathrm{kg}^{-1}$ clay) depth, respectively. These differences exist because the LLWR estimator is the soil bulk density, which varies according to the soil management.

The aim of this study was to evaluate the compaction in a Haplustox (LVd) and an Eutrustox (LVef) by means of the least limiting water range (LLWR) for corn crop.

\section{Materials and Methods}

The experiment was carried out in Jaboticabal county, São Paulo state, Brazil, located at the geographic coordinates of $21^{\circ}$ $14^{\prime} 05^{~ " S, ~} 48^{\circ} 17^{\prime} 09^{\prime} \mathrm{W}$, and altitude of $615 \mathrm{~m}$ asl. According to the classification of Köppen, the climate of the region belongs to Cwa type, with hot summers and dry winters, an average annual rainfall of $1428 \mathrm{~mm}$ and an average temperature of $21^{\circ} \mathrm{C}$ (Figure 1).

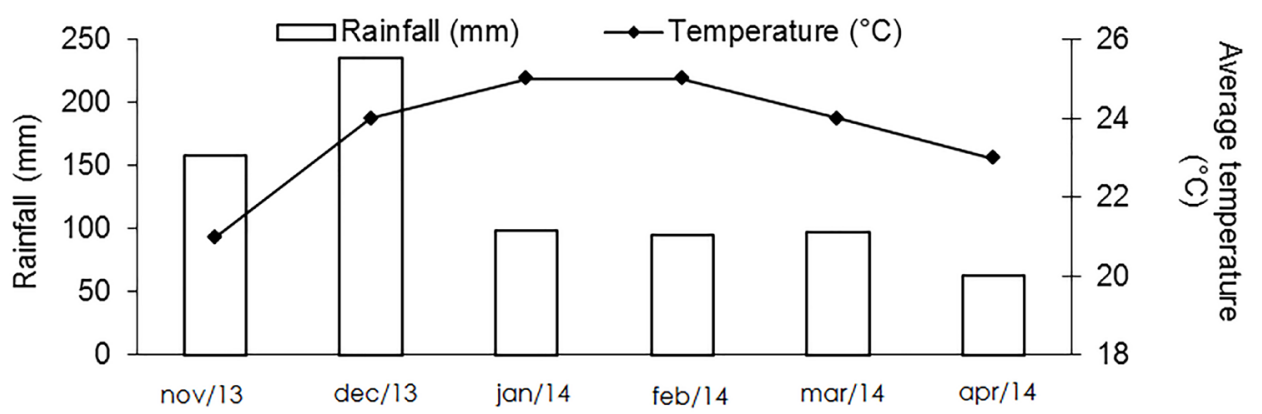

Figure 1. Accumulated rainfall and average monthly temperature during the growth cycle of corn(2013/14).

The soils were characterized by Embrapa

(2013) as a medium texture Haplustox ('Latossolo Vermelho distrófico típico" - LVd), moderate A horizon, kaolinite-hypoferric and clayey texture Eutrustox ("Latossolo Vermelho eutroférrico típico" - LVef), moderate A horizon, kaolinite-oxidic. The soils, at the layer of 0-0.20 m depth, showed 348 and $560 \mathrm{~g} \mathrm{~kg}^{-1}$ clay content, 598 and $240 \mathrm{~g} \mathrm{~kg}^{-1}$ sand content, 54 and $200 \mathrm{~g} \mathrm{~kg}^{-1}$ silt content, 2.89 and $2.74 \mathrm{Mg} \mathrm{m}^{-3}$ soil particle density, 14 and $24 \mathrm{~g}$ $\mathrm{kg}^{-1}$ soil organic matter content, in the LVd and the LVef, respectively. Before the installation of the experiments, the conventional soil preparation at $0,30 \mathrm{~m}$ depth was carried out by a disc chisel with 18 discs of $660 \mathrm{~mm}$ (26 "); and by a Marchesan Tatu off-set disk harrow, model: ATCR, with seven discs in each section (two), with discs of $0.61 \mathrm{~m}$ and distance between disks of $0.23 \mathrm{~m}$.
The experiment was arranged in a randomized block design with five treatments and four replication for each soil class. The plots were constituted by five maize rows with $6 \mathrm{~m}$ length, the three central rows were considered the useful plot, and $1.5 \mathrm{~m}$ at each end of rows were discarded. The soil compaction induction was performed on November 26, 2013, two days after rainfall, when the soil water content was close to the soil field capacity at the layer of 0-0.20 m depth.

The treatments were: $\mathrm{T0}=$ soil prepared in the conventional tillage system and without additional tractor traffic; $\mathrm{T} 1$ and $\mathrm{T} 2$ = two and four passes with a 4 t tractor, respectively; $\mathrm{T} 3$ and $\mathrm{T} 4=$ two and four passes with a $10 \dagger$ tractor, respectively. Soil compaction was then performed by passing the wheels of these 
tractors, covering the whole surface of the plots, so that the tires compressed areas parallel to each other. Therefore, the number of passes by the tractors varied according to the treatment; the traffic was overlapped on the previous one, so that whole area of each plot was passed with an equal number of times.

In order to establish $\mathrm{T} 1$ and $\mathrm{T} 2$ treatments, a Ford 5610 tractor with $56 \mathrm{~kW}(70 \mathrm{hp})$, traction $(4 \times 2)$ with $4+$ mass, whereby the distribution of $30 \%$ of the total mass in the front diagonal wheels and $70 \%$ in the rear radial wheels, was used. The inflation pressure in the $\mathrm{R} 1$ front tires was $83 \mathrm{kPa}$ whereas in the rear tires (R1 18.4-30) was $96 \mathrm{kPa}$. For the T3 and T4 treatments, a Caterpillar $924 \mathrm{~F}$ loading shovel with $105 \mathrm{~kW}$ (143 hp), traction (4 × 4), 17.5 R 25 tires, radial (L-3), $10+$ mass and with the shovel empty was used.

Corn sowing (Maximus simple hybrid) was carried out on December 03, 2013, using a no-tillage seeder-fertilizer machine with five rows. In this case and for other cultivation practices, a Massey Fergusson 620 tractor with 77 kW (105 $\mathrm{hp})$, traction $(4 \times 2$ front wheel drive assist), 7 $t$ mass whereby the distribution of $40 \%$ of the total mass in the front radial wheels and $60 \%$ in the rear radial wheels, was used. The inflation pressure in the front tires (14.9-24R1) was $95 \mathrm{kPa}$ whereas in the rear tires (19.4-34R1) was $110 \mathrm{kPa}$. The seed density ranged from five to six seeds per linear meter, with row spacing of $0.90 \mathrm{~m}$. Fertilizer application at sowing consisted of $250 \mathrm{~kg} \mathrm{ha}^{-1}$ of the N-P-K formulation (8-28-16) and $30 \mathrm{~kg} \mathrm{ha}^{-1}$ of zinc sulfate to obtain 6-8 $\mathrm{Mg} \mathrm{ha}^{-1}$ expected corn yield. The top-dressing fertilizer application was performed at $\mathrm{V} 6$ growth stage with $230 \mathrm{~kg} \mathrm{ha}^{-1}$ of the N-P-K formulation (30-0-10) on the surface, next to the seeding row.

On December 17 and 18, 2013, two groups of six samples per treatment were collected in each soil in the row spacing using $53.1610^{-6} \mathrm{~m}^{3}$ cylinders $(0.032 \mathrm{~m}$ high and $0.046 \mathrm{~m}$ diameter), at the layers of $0-0.05,0.05-0.10$ and $0.10-0.20 \mathrm{~m}$ depth, totaling 360 samples in the experiment. Thereafter, a sample of each group and layer was saturated for $24 \mathrm{~h}$ and tensions of $-60,-100,-330,-600,-1000$ and $-3000 \mathrm{hPa}$ matric potential were applied, using a pressure plate apparatus (Richards). At equilibrium, the samples were weighed and soil penetration resistance (PR) was determined. The PR was determined by using a static electronic penetrometer with a constant penetration velocity of $1 \mathrm{~cm} \mathrm{~min}^{-1}$, a cone with a $30^{\circ}$ angle and a base area of 4.909 $10^{-6} \mathrm{~m}^{2}$, equipped with a linear actuator and a $20 \mathrm{Kg}$ load cell coupled to a microcomputer for data acquisition. The results were obtained in $\mathrm{kgf}$ and transformed in MPa using the following equation: readings / $0.046 \times 0.098$. The samples were dried in a stove at $105^{\circ} \mathrm{C}$ for $24 \mathrm{~h}$ in order to determine the water content at each soil tension and bulk density (BD) (Grossman \& Reinsch, 2002). Microporosity was obtained in the water retained at $-100 \mathrm{hPa}$ matric potential (Flint \& Flint, 2002), and macroporosity by the difference between total porosity and microporosity.

For determination of the LLWR, the soil water retention curve was adjusted by the nonlinear model used by Silva et al. (1994) and the soil penetration resistance (PR) curve was adjusted using the Busscher (1990) model, in log-transformed data. SAS software was used to perform the analysis (Statistical analysis system, version 9.2):

$$
\begin{array}{ll}
\ln \theta=a+b B D+\ln \psi & \text { Eq. (1) } \\
\ln P R=\ln d+e \ln +f \ln B D & \text { Eq. (2) }
\end{array}
$$

where $\theta$ : volumetric water content $\left(\mathrm{m}^{3} \mathrm{~m}^{-3}\right) ; \psi$ : soil water tension (hPa); a, b, c, d, e, f: parameters of the model adjusting.

The water content in the field capacity $\left(\theta_{F C}\right)$ is the water retained in the tension of -100 $\mathrm{hPa}$ and the permanent wilting point $\left(\theta_{\mathrm{PWP}}\right)$ is the water retained in the tension of $-15000 \mathrm{hPa}$. The $\theta_{F C}$ and $\theta_{P W P}$ were estimated by equations ( 3 ) and (4), respectively, obtained from equation (1):

$$
\begin{array}{ll}
\theta_{\mathrm{FC}}=\operatorname{EXP}(a+b B D) * 100^{c} & \text { Eq. (3) } \\
\theta_{P W P}=\operatorname{EXP}(a+b B D) * 15.000^{c} & \text { Eq. (4) }
\end{array}
$$

The water content from which RP is limiting was estimated by equation (5), obtained from equation (2):

$$
\theta_{P R}=\left((P R C) /\left(\operatorname{EXPd} *\left(B D^{e}\right)\right)\right)^{1 / f} \quad \text { Eq. (5) }
$$

where PRc is the critical PR of $2 \mathrm{MPa}$. 
The water content in which the aeration porosity is $10 \%$ was calculated by the equation (6):

$$
\theta_{A P}=[(1-(B D / P d)]-0.10 \quad \text { Eq. (6) }
$$

where Pd is soil particle density $\left(\mathrm{g} \mathrm{dm}^{-3}\right)$.

The $\theta_{A P}, \theta_{F C^{\prime}}, \theta_{P W P}$ and $\theta_{P R}$ were plotted as a function of the $B D$, forming the LLWR, representative of the three layers (0-0.20 m), since it was equivalent in all layers, thus, the average value was used.

On April 29, 2014, after the stage of physiological maturity of the grains, the grain mass was evaluated in 20 plants per plot. When grain moisture was greater than $25 \%$, corn cobs of two useful row with $2.0 \mathrm{~m}$ length were harvested (0.5 $\mathrm{m}$ was discarded at each end of the 3.0 $\mathrm{m}$ row), for the threshing and the grain mass determination. Corn grain yield was obtained by extrapolating grain yield from the useful plot area to $1 \mathrm{ha}$, adjusting grain moisture to $13 \%$. The analysis of variance and Tukey's test ( $p<0.05$ ) were performed. Also, correlations between soil bulk density, and plant height and corn yield were performed.

Table 1. F values calculated by the analysis of variance for the physical attributes of an LVd and an LVef in different layers and compaction levels.

\begin{tabular}{|c|c|c|c|c|}
\hline $\begin{array}{l}\text { Sources of } \\
\text { variation }\end{array}$ & Macroporosity & Microporosity & Bulk density & $\begin{array}{c}\text { Penetration } \\
\text { resistance }\end{array}$ \\
\hline \multicolumn{5}{|c|}{ LVd } \\
\hline Treatment $(T)$ & $2.61^{\mathrm{ns}}$ & $4.32^{\text {ns }}$ & $4.54^{\mathrm{ns}}$ & $1.73^{\text {ns }}$ \\
\hline Layer (L) & $1.24^{\mathrm{ns}}$ & $0.72^{\text {ns }}$ & $1.75^{\mathrm{ns}}$ & $0.08^{\text {ns }}$ \\
\hline$T \times L$ & $0.48^{\text {ns }}$ & $0.70^{\text {ns }}$ & $0.77^{\text {ns }}$ & $0.71^{\mathrm{ns}}$ \\
\hline $\mathrm{CV}(\%)^{1}$ & 27.18 & 12.85 & 8.24 & 22.05 \\
\hline $\mathrm{CV}(\%)^{2}$ & 26.47 & 10.57 & 4.64 & 24.99 \\
\hline \multicolumn{5}{|c|}{ LVef } \\
\hline Treatment ( $\mathrm{T}$ ) & $6.54^{*}$ & $7.30^{*}$ & $5.31^{*}$ & $2.42^{\text {ns }}$ \\
\hline Layer (L) & $1.40^{\mathrm{ns}}$ & $0.64^{\mathrm{ns}}$ & $0.27^{\mathrm{ns}}$ & $1.17^{\mathrm{ns}}$ \\
\hline$T \times L$ & $0.98^{\text {ns }}$ & $0.66^{\mathrm{ns}}$ & $0.89^{\text {ns }}$ & $1.38^{\text {ns }}$ \\
\hline $\mathrm{CV}(\%)^{1}$ & 18.53 & 2.74 & 3.61 & 21.98 \\
\hline $\mathrm{CV}(\%)^{2}$ & 24.66 & 3.36 & 4.43 & 24.58 \\
\hline
\end{tabular}

Table 2. Average values and standard errors of physical attributes in a Haplustox ("Latossolo Vermelho Distrófico" - LVd) in different layers and compaction levels.

\begin{tabular}{|c|c|c|c|c|c|}
\hline \multirow[b]{2}{*}{ Layer } & \multicolumn{5}{|c|}{ LVd } \\
\hline & TO & $\mathrm{Tl}$ & $\mathrm{T} 2$ & T3 & $\mathrm{T} 4$ \\
\hline$m$ & \multicolumn{5}{|c|}{ Macroporosity $\left(\mathrm{m}^{3} \mathrm{~m}^{-3}\right)$} \\
\hline $0-0.05$ & $0.239 \pm 0.10^{(1)}$ & $0.138 \pm 0.02$ & $0.129 \pm 0.02$ & $0.163 \pm 0.01$ & $0.144 \pm 0.05$ \\
\hline $0.05-0.10$ & $0.227 \pm 0.03$ & $0.133 \pm 0.02$ & $0.114 \pm 0.00$ & $0.090 \pm 0.04$ & $0.122 \pm 0.02$ \\
\hline $0.10-0.20$ & $0.217 \pm 0.05$ & $0.143 \pm 0.02$ & $0.145 \pm 0.00$ & $0.100 \pm 0.00$ & $0.103 \pm 0.01$ \\
\hline \multirow[t]{2}{*}{ Average } & $0.228 \pm 0.06 a$ & $0.138 \pm 0.02 a$ & $0.129 \pm 0.00 a$ & $0.118 \pm 0.02 a$ & $0.123 \pm 0.03 a$ \\
\hline & \multicolumn{5}{|c|}{ Microporosity $\left(\mathrm{m}^{3} \mathrm{~m}^{-3}\right)$} \\
\hline $0-0.05$ & $0.176 \pm 0.05$ & $0.195 \pm 0.02$ & $0.219 \pm 0.02$ & $0.210 \pm 0.01$ & $0.204 \pm 0.02$ \\
\hline $0.05-0.10$ & $0.163 \pm 0.01$ & $0.193 \pm 0.00$ & $0.228 \pm 0.00$ & $0.254 \pm 0.02$ & $0.213 \pm 0.02$ \\
\hline $0.10-0.20$ & $0.177 \pm 0.02$ & $0.209 \pm 0.02$ & $0.220 \pm 0.00$ & $0.222 \pm 0.00$ & $0.229 \pm 0.00$ \\
\hline \multirow[t]{2}{*}{ Average } & $0.172 \pm 0.03 a$ & $0.199 \pm 0.02 a$ & $0.222 \pm 0.00 a$ & $0.229 \pm 0.01 a$ & $0.215 \pm 0.01 a$ \\
\hline & \multicolumn{5}{|c|}{ Bulk density $\left(\mathrm{kg} \mathrm{dm}^{-3}\right)$} \\
\hline $0-0.05$ & $1.54 \pm 0.13$ & $1.72 \pm 0.01$ & $1.73 \pm 0.09$ & $1.67 \pm 0.02$ & $1.91 \pm 0.04$ \\
\hline $0.05-0.10$ & $1.55 \pm 0.08$ & $1.78 \pm 0.06$ & $1.84 \pm 0.06$ & $1.75 \pm 0.06$ & $1.92 \pm 0.08$ \\
\hline $0.10-0.20$ & $1.56 \pm 0.18$ & $1.65 \pm 0.00$ & $1.68 \pm 0.02$ & $1.79 \pm 0.02$ & $1.87 \pm 0.03$ \\
\hline \multirow[t]{2}{*}{ Average } & $1.55 \pm 0.13 b$ & $1.72 \pm 0.02 \mathrm{ab}$ & $1.75 \pm 0.06 a b$ & $1.74 \pm 0.03 a b$ & $1.90 \pm 0.05 a$ \\
\hline & \multicolumn{5}{|c|}{ Penetration resistance (MPa) } \\
\hline $0-0.05$ & $2.90 \pm 0.73$ & $4.29 \pm 0.87$ & $4.04 \pm 0.47$ & $1.95 \pm 0.20$ & $4.52 \pm 1.01$ \\
\hline $0.05-0.10$ & $3.19 \pm 0.79$ & $3.93 \pm 0.02$ & $3.60 \pm 0.14$ & $2.12 \pm 0.29$ & $3.78 \pm 0.22$ \\
\hline $0.10-0.20$ & $2.55 \pm 1.03$ & $3.85 \pm 1.86$ & $3.32 \pm 1.23$ & $4.10 \pm 0.13$ & $3.31 \pm 0.93$ \\
\hline Average & $2.88 \pm 0.85 a$ & $4.02 \pm 0.92 \mathrm{a}$ & $3.65 \pm 0.61 \mathrm{a}$ & $2.72 \pm 0.21 a$ & $3.87 \pm 0.72 a$ \\
\hline
\end{tabular}




\section{Results and Discussion}

There was no interaction between compaction treatments and the soil layers, in the LVd and LVef for the soil bulk density (BD), macroporosity, microporosity, and soil penetration resistance (PR) (Table 1). The lowest $\mathrm{BD}$ average value was found in the TO (without additional machine traffic), however, it was statistically different only compared to the T4 (four passes with a 10 t tractor) in the LVd (Table 2). Even so, macroporosity in this soil was similar for all treatments.

It was verified that the increase in the number of passes and the tractor mass in both soils, LVd and LVef (Table 3) did not cause changes in the BD values for the $\mathrm{Tl}$ (two passes with a $4 \mathrm{t}$ tractor), T2 (four passes with a $4 t$ tractor), T3 (two passes with a $10 t$ tractor) and T4. This occurs due to the first pass of the tractor on the surface layer of the soil promotes a greater compaction in comparison to the subsequent passes, since the larger pores undergo a greater degradation with the initial traffic. After that, there is the presence of a larger number of smaller pores and more resistant to soil deformation.

Table 3. Average values and standard errors of physical attributes in an Eutrustox ("Latossolo Vermelho Eutroférrico " - LVef) in different layers and compaction levels.

\begin{tabular}{|c|c|c|c|c|c|}
\hline \multirow[b]{2}{*}{ Layer } & \multicolumn{5}{|c|}{ LVef } \\
\hline & TO & $\mathrm{Tl}$ & $\mathrm{T} 2$ & T3 & T4 \\
\hline$m$ & \multicolumn{5}{|c|}{ Macroporosity $\left(\mathrm{m}^{3} \mathrm{~m}^{-3}\right)$} \\
\hline $0.05-0.08$ & $0.179 \pm 0.03^{(1)}$ & $0.137 \pm 0.00$ & $0.095 \pm 0.01$ & $0.079 \pm 0.01$ & $0.077 \pm 0.03$ \\
\hline $0.12-0.15$ & $0.118 \pm 0.03$ & $0.118 \pm 0.00$ & $0.089 \pm 0.01$ & $0.095 \pm 0.01$ & $0.098 \pm 0.00$ \\
\hline $0.15-0.18$ & $0.141 \pm 0.03$ & $0.128 \pm 0.02$ & $0.124 \pm 0.02$ & $0.113 \pm 0.00$ & $0.118 \pm 0.02$ \\
\hline \multirow[t]{2}{*}{ Average } & $0.146 \pm 0.03 a$ & $0.128 \pm 0.00 \mathrm{ab}$ & $0.103 \pm 0.01 \mathrm{ab}$ & $0.096 \pm 0.00 \mathrm{~b}$ & $0.098 \pm 0.02 \mathrm{ab}$ \\
\hline & \multicolumn{5}{|c|}{ Microporosity $\left(\mathrm{m}^{3} \mathrm{~m}^{-3}\right)$} \\
\hline $0.05-0.08$ & $0.373 \pm 0.02$ & $0.382 \pm 0.01$ & $0.408 \pm 0.01$ & $0.405 \pm 0.03$ & $0.410 \pm 0.01$ \\
\hline $0.12-0.15$ & $0.388 \pm 0.02$ & $0.388 \pm 0.00$ & $0.410 \pm 0.01$ & $0.373 \pm 0.02$ & $0.404 \pm 0.00$ \\
\hline $0.15-0.18$ & $0.378 \pm 0.00$ & $0.382 \pm 0.00$ & $0.404 \pm 0.00$ & $0.403 \pm 0.01$ & $0.385 \pm 0.01$ \\
\hline \multirow[t]{2}{*}{ Average } & $0.380 \pm 0.01 \mathrm{~b}$ & $0.384 \pm 0.00 \mathrm{ab}$ & $0.407 \pm 0.00 a$ & $0.394 \pm 0.02 a b$ & $0.400 \pm 0.00 \mathrm{ab}$ \\
\hline & \multicolumn{5}{|c|}{ Bulk density $\left(\mathrm{kg} \mathrm{dm}^{-3}\right)$} \\
\hline $0.05-0.08$ & $1.32 \pm 0.08$ & $1.36 \pm 0.01$ & $1.51 \pm 0.08$ & $1.45 \pm 0.03$ & $1.51 \pm 0.07$ \\
\hline $0.12-0.15$ & $1.42 \pm 0.08$ & $1.41 \pm 0.01$ & $1.49 \pm 0.05$ & $1.43 \pm 0.02$ & $1.40 \pm 0.01$ \\
\hline $0.15-0.18$ & $1.35 \pm 0.02$ & $1.40 \pm 0.03$ & $1.45 \pm 0.02$ & $1.45 \pm 0.00$ & $1.40 \pm 0.01$ \\
\hline \multirow[t]{2}{*}{ Average } & $1.36 \pm 0.06 b$ & $1.39 \pm 0.02 \mathrm{ab}$ & $1.48 \pm 0.05 a$ & $1.44 \pm 0.02 \mathrm{ab}$ & $1.44 \pm 0.03 a b$ \\
\hline & \multicolumn{5}{|c|}{ Penetration resistance (MPa) } \\
\hline $0.05-0.08$ & $0.83 \pm 0.53$ & $0.99 \pm 0.03$ & $2.11 \pm 0.44$ & $2.39 \pm 0.53$ & $2.99 \pm 1.13$ \\
\hline $0.12-0.15$ & $1.66 \pm 0.19$ & $1.49 \pm 0.04$ & $1.76 \pm 0.53$ & $1.91 \pm 0.17$ & $1.51 \pm 0.09$ \\
\hline $0.15-0.18$ & $1.14 \pm 0.40$ & $1.19 \pm 0.45$ & $1.23 \pm 0.35$ & $1.80 \pm 0.06$ & $1.99 \pm 0.09$ \\
\hline Average & $1.21 \pm 0.37 \mathrm{a}$ & $1.22 \pm 0.17 a$ & $1.70 \pm 0.44 a$ & $2.03 \pm 0.25 a$ & $2.16 \pm 0.44 a$ \\
\hline
\end{tabular}

Macroporosity values close to or higher than $0.10 \mathrm{~m}^{3} \mathrm{~m}^{-3}$ were verified after tractor traffic in the LVd and LVef. This value is considered as the minimum necessary for water flowing and gaseous exchanges between the external environment and the soil, and critical for the root growth of most crops.

In the LVd, the BD average absolute values of all treatments were higher than those found in the LVef. This result is due to the mineralogy since the sand content and the particle density $(2.89$ $\mathrm{Mg} \mathrm{m}^{-3}$ ) in the LVd are higher than in the LVef. This is due to the predominance of quartz and kaolinite with massive structure, which confers lower porosity in the LVd. Despite the statistically significant increase of BD for the T4 compared to $\mathrm{TO}$, at the layer of 0-0.20 m depth, in the LVd, it was not observed reducing of corn grain yield (Figure 2a). The corn yield in this soil showed a quadratic behavior as a function of $B D$, however, it was not significant. From the BD value of $1.73 \mathrm{~kg}$ $\mathrm{dm}^{-3}$, the maximum yield of $5.30 \mathrm{tha}^{-1}$ decreased by $21.32 \%$ for the T4. It can be observed in Figure 1 that the development of the crop manifested agronomic changes due to the scarcity of rainfall during the 2013/14 growing season. Rainfall was only $291 \mathrm{~mm}$ from January to March 2014 (Figure 1) and probably resulted in water stress. 


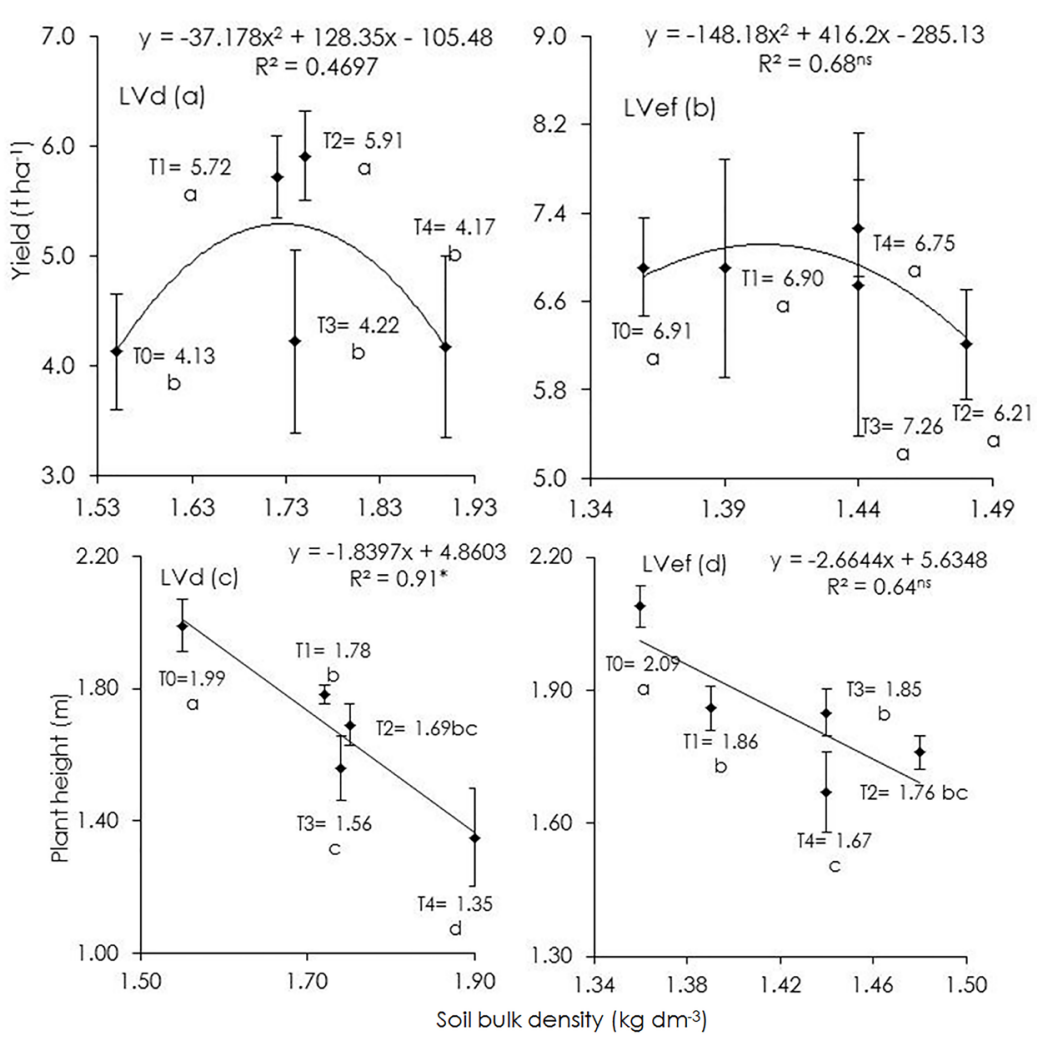

Figure 2. Correlation between soil bulk density, and corn yield, and plant height in an LVd and an LVef. ( $a, b, c$, and d). The bars refer to the standard errors of the means. * Significant ( $p<0.05)$ and ${ }^{\text {ns: non-significant. }}$

In the same way as in the LVd, changes in the BD and PR in the LVef were not justified in relation to corn yield (Tables 2 and 3), mainly in relation to the inferiority of $\mathrm{BD}$ in the TO compared to the T2. It was estimated that when the $\mathrm{BD}$ in the LVef reached $1.40 \mathrm{~kg} \mathrm{dm}^{-3}$, the maximum yield was $7.12 \mathrm{tha}^{-1}$ and from that point it was observed an increase of $1.97 \%$ and a decrease of $12.78 \%$ of yield in the T3 and T2, respectively, despite the non-significant behavior of the regression for these parameters. Observing the absolute values, the crop yield in the LVef showed a greater expression than in the LVd. This occurred due to the higher organic matter content and clay content in the LVef, which favored a greater water adsorption. The corn height showed a linear negative response to the $\mathrm{BD}$ in both soils. The TO showed the best performance, although the coefficient of determination $\left(\mathrm{R}^{2}\right)$ was significant only for the LVd condition. Therefore, there is an indication that the plants that received additional compaction found limitations for growing compared to the treatments under conventional tillage.
The coefficients of determination indicate that the water retention curve explained 66 and $84 \%$ of the water content $(\theta)$, and the soil penetration resistance curve explained 78 and $75 \%$ of the PR for the LVd and LVef, respectively (Table 4). The least limiting water range (LLWR) values corresponding to the gray-hatched area in the graphic (Figure 3). The LLWR in the LVef was higher than in the LVd (Figure 3). It was observed a reduction of the LLWR as the BD values increase, as already stated by Silva et al. (1994) and Blainski et al. (2012). The $\theta$ and the RP (Table 4) were negatively correlated with the matric potential and positively with the $\mathrm{BD}$, due to the negative sign of the parameters $c$ and $e$, and the positive sign of the parameters $b$ and $f$, of each equation in the LVef and LVd. On the other hand, the behavior in the LVd was discordant with respect to the e and $f$ coefficients.

The upper limit of the LLWR (Figure 3) was the water content in the field capacity $\left(\theta_{F C}\right)$ in the $L V d$, until PR becomes limiting in the $L V d$ $\left(\theta_{P R}\right)$. The effect of RP on the LLWR (gray-hatched area ) evidences the process of soil physical 
Table 4. Soil water retention curve and soil penetration resistance curve for an LVd and an LVef at the layer of 0-0.20 m depth for different agricultural management systems.

\begin{tabular}{lll}
\hline Soil & Soil water retention curve & Soil penetration resistance curve \\
LVd & $\theta=-2,18591 \mathrm{Bd}^{0,96151} \Psi^{-0,07325} R^{2}=0,66^{* *}$ & $P R=-5,27041 \theta^{4,71292} \mathrm{Bd}^{-2,39073} R^{2}=0,78^{* *}$ \\
LVef & $\theta=-1,40337 \mathrm{Bd}^{0,78836} \Psi^{-0,08478} R^{2}=0,84^{* *}$ & $P R=-3,98142 \theta^{-1,42965} \mathrm{Bd}^{10,03552} R^{2}=0,75^{* *}$ \\
\hline significant at 1\%.
\end{tabular}
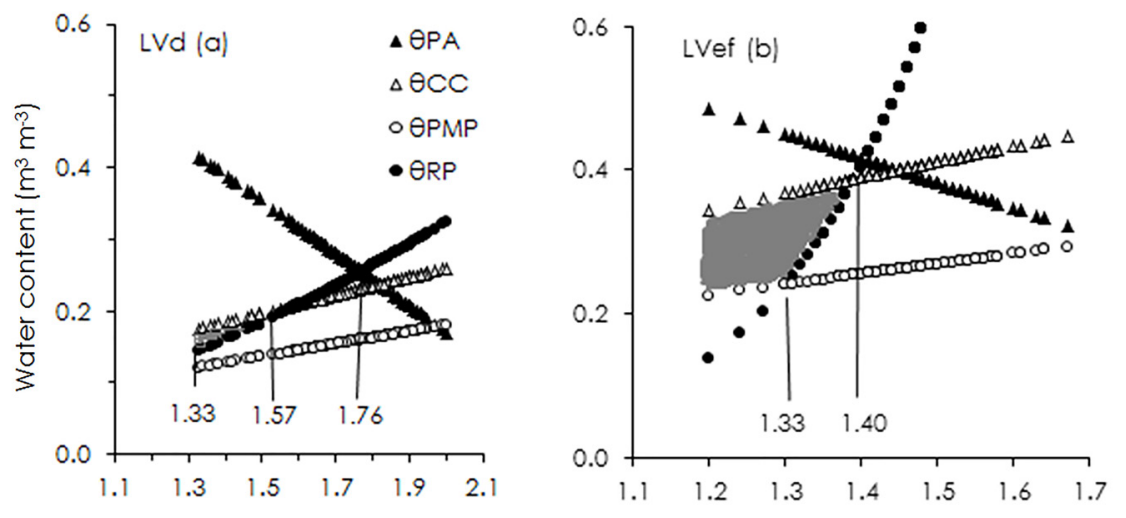

Soil bulk density ( $\left.\mathrm{Mg} \mathrm{m}^{-3}\right)$

Figure 3. Soil water content $(\theta)$ as a function of soil bulk density in an LVd (a), and an LVef (b), for critical limits of aeration porosity $\left(\theta_{A P}\right)$, field capacity $\left(\theta_{F C}\right)$, permanent wilting point $\left(\theta_{\text {PWP }}\right)$ and soil penetration resistance $\left(\Theta_{P R}\right)$. RPC of $2 \mathrm{MPa}$ at the layer of $0-0.20 \mathrm{~m}$ depth. The least limiting water range (LLWR) values corresponding to the gray-hatched area.

degradation since it starts to restrict the water range where the roots can grow and develop within the available water range (Cavalieri et al., 2011). Using the critical PR of $2 \mathrm{MPa}$ in the LVd, the LLWR lower limit was the $\theta_{P R}$. While in the LVef this limit showed the water content at the permanent wilting point $\left(\theta_{\text {PWP }}\right)$ only for BD values $\leq 1.33$. Since, from values higher than these, the $\theta_{P R}$ has become the LLWR lower limit. Thus, in the LVef there is a more restricted amplitude of BD compared to the LVd. It indicates that the higher the BDc, the less chance the plant will remain under stress conditions.

The restriction of $\theta_{P R}$ in the LVd occurs in $\mathrm{BD}$ ranging from 1.33 to $1.57 \mathrm{Mg} \mathrm{m}^{-3}$ and coincides with the beginning of the LLWR limit in the condition of $\mathrm{BD}=1.83 \mathrm{Mg} \mathrm{m}^{-3}$. For the condition in the LVef, this impediment occurred in BD ranging from 1.33 to $1.40 \mathrm{Mg} \mathrm{m}^{-3}$. While for the condition in the LVd only the T4 showed restriction.

Regardless of the soil class, the available water content (AWC $=\theta_{F C}-\theta_{\text {PWP }}$ ) was always higher than the LLWR, which characterizes the soils as physically degraded. Due to such behavior, Silva et al. (1994) point out the LLWR as a tool for analysis of soil structure more sensitive than the concept of available water. In general, in managed soils, LLWR is limited in the upper limit by the $\theta_{F C}$ and in the lower limit by the $\theta_{P R}$ as verified by Guimarães et al. (2013) in a sandy loam LVd. These authors affirmed that it was considered the LLWR lower limit for the entire range of $\mathrm{BD}$, excepted for the native forest. In this study, this behavior did not occur in the LVef.

The LLWR amplitude in the LVd ranged from 0.01 to $0.04 \mathrm{~m}^{3} \mathrm{~m}^{-3}$ and in the LVef ranged from 0.03 to $0.13 \mathrm{~m}^{3} \mathrm{~m}^{-3}$. The difference of this amplitude was $0.03 \mathrm{~m}^{3} \mathrm{~m}^{-3}$ in the LVd and 0.10 $\mathrm{m}^{3} \mathrm{~m}^{-3}$ in the LVef. The amplitude values of the LLWR were similar to those found by Blainski et al. (2012), who verified a variation of 0 to $0.11 \mathrm{~m}^{3} \mathrm{~m}^{-3}$, which is characteristic of the textural class of red Oxisols.

A similar condition of the LLWR variation in the LVd found in the present study was also verified by Lima et al. (2015) in an Oxisol 
(607 $\mathrm{g} \mathrm{kg} \mathrm{k}^{-1}$ clay content) with 0-0.04 $\mathrm{m}^{3} \mathrm{~m}^{-3}$ water content in the PRc of $2 \mathrm{MPa}$ at the layer of $0-0.20 \mathrm{~m}$ depth. According to the results, tractors-induced pressures on the soils led to a soil structure degradation process. Narrower LLWR range found in the $L V d$ compared to that found in the LVef in this present study reaffirms the comment by Neves Jr. (2013) that the range in which the soil water content can vary without any restrictions related to the availability of water, aeration porosity and soil resistance to root penetration is narrow.

BDC is influenced by soil management and has an inverse relationship with soil clay content (Reichert et al., 2009), as evidenced in this study. In an integrated crop-livestock systems, Fidalski et al. (2013) observed in a sandy/medium texture LVd with PRc equal to $2.5 \mathrm{MPa}$, that the $\mathrm{BDC}$ values were $1.66,1.64$ and $1.62 \mathrm{Mg} \mathrm{m}^{-3}$ at the layers of $0-0.10 ; 0.10-0.20$, and $0.20-0.30 \mathrm{~m}$ depth, respectively. In a medium texture LVd submitted to different compaction conditions at the $0.30 \mathrm{~m}$ depth, Freddi et al. (2009) found $1.46 \mathrm{Mg} \mathrm{m}^{-3} \mathrm{BDC}$ after using PRc of 2.15 MPa. A similar situation was observed by Pereira et al. (2010), who verified $\mathrm{BDC}$ values of $1.43 \mathrm{Mg} \mathrm{m}^{-3}$ for conventional tillage and values higher and lower than $1.43 \mathrm{Mg}^{-3}$ for different no-tillage systems, in a medium texture LVd at the $0.20 \mathrm{~m}$ depth with $2 \mathrm{MPa}$ PRc. The difference in BDc can also be attributed to the soil class, according to Romero et al. (2014) who found BDC of 1.62 to $1.38 \mathrm{Mg} \mathrm{m}^{-3}$ in a clayey LVd and in a very clayey Oxisol ("Latossolo Vermelho Amarelo" - LVA), respectively, at the layer of 0.40$0.60 \mathrm{~m}$ depth with PRc of $1 \mathrm{MPa}$.

The restriction for the penetration resistance in the $\mathrm{LVd}$ occurred from $1.33 \mathrm{Mg}$ $\mathrm{m}^{-3} \mathrm{BD}$ value and coincides with the starting of the LLWR limit. In the LVd, all treatments with additional compaction showed limitations imposed by field capacity, since their BD values were higher than $1.57 \mathrm{Mg} \mathrm{m}^{-3}$. In the LVd, all treatments with additional compaction showed limitations imposed by field capacity since their $\mathrm{BD}$ values were higher than $1.57 \mathrm{Mg} \mathrm{m}^{-3}$. In the TO for the LVef, there would be a restriction for the PR, independently of the water content that remained in the field capacity, since the $\mathrm{BD}$ values were lower than $1.40 \mathrm{Mg} \mathrm{m}^{-3}$.

Therefore, the management of the machines during the implementation of the treatments in the LVd resulted in severe restrictions to the LLWR, added to the low rainfall, resulting in low corn yield. Thus, the choice of the application of the treatments submitted to the LVd provided physical degradation in this soil by increasing its $B D$ and PR. The LLWR in the LVd is small, on the other hand, the BD values already start at 1.30 $\mathrm{Mg} \mathrm{m}-3$ and increase to extreme values. Thus, in most samples the LLWR was zero, that is, the condition is not ideal for plant growth. The treatments $\mathrm{TO}$ and $\mathrm{T} 1$ in the LVef are considered tolerable, according to the LLWR values (Table 3). The use of less favorable managements to the growth and development of the corn crop in the LVd and LVef areas should be avoided in order not to compromise the soil structure. Since, the practice of subsoiling for the soil decompaction has a high operational cost and high energy demand (Cortez, 2013). In summary, reducing soil compaction is vital to ensure high LLWR values in agricultural management systems, because an increase in soil bulk density requires high soil water content to maintain soil resistance under non-limiting cultivation conditions (Souza et al., 2015).

Thus, the results of this study indicate that the LLWR is efficient in detecting unfavorable conditions to crop development and corroborates the recommendations of Blainski et al. (2012). These authors state that the LLWR is a robust indicator of the physical quality of agricultural soils. In addition to this, the LLWR is considered a well-established index to assess the quality of cultivated soils (Cavalieri et al., 2011). Therefore, the results of this study agree with the results of several authors who emphasize that the LLWR is a more sensitive parameter than the soil water retention curve to evaluate changes in soil structure (Roque et al., 2011; Silva et al., 2011 e Guedes Filho et al., 2013).

\section{Conclusions}

The treatments submitted to the LVd provided physical degradation by increasing $B D$ and $\mathrm{PR}$, added to lower clay and organic matter content of this soil comparing to the LVef. 
The determination of the LLWR was efficient and complementary for identifying more favorable or more impeditive conditions to the compaction in the LVef for the corn crop development in relation to the LVd.

\section{Acknowledgements}

To CAPES Foundation, Ministry of Education of Brazil by granting a scholarship.

\section{References}

Blainski, E., Tormena, C.A., Guimarães, R.M.L., Nanni, M.R.R. 2012. Qualidade física de um Latossolo sob plantio direto influenciada pela cobertura do solo. Revista Brasileira de Ciência do Solo 36: 79-87.

Busscher, W.J. Adjustment of flat-tipped penetrometer resistance data to a common water content. 1999. American Society of Agricultural Engineers 33: 519-524.

Cavalieri, K.M.V., Carvalho, L.A., Silva, A.P., Libardi, P.L., Tormena, C.A. 2011 . Qualidade física de três solos sob colheita mecanizada de canade-açúcar. Revista Brasileira de Ciência do Solo 35: 1541-1549, 2011.

Cortez, L.A. 2013. Subsolagem em profundidade variada com base no mapeamento de áreas de manejo específico. 57f. (Tese de Mestrado)Universidade Estadual Paulista, Jaboticabal, Brasil.

Embrapa. Empresa Brasileira de Pesquisa Agropecuária. 2013. Sistema Brasileiro de Classificação de Solos. Centro Nacional de Pesquisas de Solos, Brasília, Brasil. 353p.

Fidalski, J., Tormena, C.A., Alves, S.J. 2013. Intervalo hídrico ótimo de um Latossolo Vermelho distrófico após o primeiro período de pastejo contínuo de Brachiaria ruziziensis, em sistema integração lavoura-pecuária. Revista Brasileira de Ciência do Solo 37: 775-783, 2013.

Flint, L.E., Flint, A.L. 2002. Porosity. In: Dane, J.H., Topp, G.C. (ed.). Methods of soil analysis: Physical methods. Soil Science Society of America, Madison, Estados Unidos. p. 241-53.

Freddi, O.S., Centurion, J.F., Duarte, A.P., Peres, F.S.C. 2009. Compactação do solo e produção de cultivares de milho em Latossolo Vermelho. II-Intervalo hídrico ótimo e sistema radicular. Revista Brasileira de Ciência do Solo 33: 805-818.

Gubiani, P.I.; Goulart, R.Z.; Reichert, J.M., Reinert, D.J. 2013. Crescimento e produção de milho associados com o intervalo hídrico ótimo. Revista Brasileira de Ciência do Solo 37: 1502-1511.
Guedes Filho, O., Blanco-Canqui, H., Silva, A.P. 2013. Least limiting water range of the soil seedbed for long-term tillage and cropping systems in the central Great Plains, USA. Geoderma 99-1 10: 207208.

Guimarães, R.M.L., Tormena, C.A., Blainski, E., Fidalski, J. Intervalo hídrico ótimo para avaliação da degradação física do solo. 2013. Revista Brasileira de Ciência do Solo 37: 1512-1521.

Grossman, R.B., Reinsch, T.G. 2002. The solid phase, bulk density and linear extensibility. In: Dane, J.H., Topp, G.C. (ed.). Methods of soil analysis: Physical methods. Soil Science Society of America, Madison, Estados Unidos. p. 201-228.

Lima, C.L.R., Suzuki, L.E.A.S., Reinert, D.J., Reichert, J.M. 2015. Least limiting water range and degree of compactness of soils under no-tillage. Bioscience Journal 31: 1071-80.

Neves Jr, A.F., Silva, A.P., Noronha, N.C., Cerri, C.C. 2013. Sistemas de manejo do solo na recuperação de uma pastagem degradada em Rondônia. Revista Brasileira de Ciência do Solo 37: 232-241.

Omuto, C.T. Assessment of soil physical degradation in Estern Kenya by use of a sequential soil testing protocol. 2008. Agriculture, Ecosystems \& Environment 128: 199-211.

Pereira, F.S., Andrioli, I., Beutler, A.N., Almeida, C.X., Pereira, F.S. 2010. Physical quality of an Oxisol cultivated with maize submitted to cover crops in the pre-cropping period. Revista Brasileira de Ciência do Solo 34: 211-218.

Reichert, J.M., Suzuki, L.E.A.S., Reinert, D.J., Horn, R., Haakansson, I. 2009. Reference bulk density and critical degree-of-compactness for no-till crop production in subtropical highly weathered soils. Soil Tillage and Research 102; 242-254.

Romero, E.M., Ruiz, H.A., Fernandes, R.B.A., Costa, L.M. 2014. Condutividade hidraúlica, porosidade, resistência mecânica e intervalo hídrico ótimo em Latossolo artificialmente compactados. Revista Brasileira de Engenharia Agrícola e Ambiental 18: 1003-1009.

Roque, A.A.O., Souza, Z.M., Araújo, F.S., Silva, G.R.V. 2011. Atributos físicos do solo e intervalo hídrico ótimo de um Latossolo Vermelho distrófico sob controle agrícola. Ciência Rural 41: 1536-1542.

Silva, A.P., Kay, B.D., Perfect, E. 1994. Characterization of the least limiting water range of soils. Soil Science Society of American Journal 58: 1775-1781. 
Silva, G.L., Lima, H.V., Campanha, M.M., Gilkes, R.J., Oliveira, T.S. 2011. Soil physical quality of Luvisols under agroforestry natural vegetation and conventional crop management systems in the Brazilian semi-arid region. Geoderma 167168: 61-70.

Souza, G.S., Souza, Z.M., Cooper, M., Tormena, C.A. 2015. Controlled traffic and soil physical quality of an Oxisol under sugarcane cultivation. Scientia Agricola 72: 270-277. 